\title{
Mathematical Modeling and Simulation of Photovoltaic Array
}

\author{
Tomáš Skočil ${ }^{1}$, Manuel Pérez Donsión ${ }^{2}$ \\ ${ }^{1}$ Department of Electric Power Engineering and Ecology \\ Faculty of Electrical Engineering, University of West Bohemia, Pilsen \\ Univerzitní 26; 30614 Plzeň; Czech Republic \\ phone: (+420) 6055730 21, e-mail: tskocil@kee.zcu.cz, skocil.tomas@gmail.com \\ 2 Department of Electrical Engineering, \\ Faculty of Industrial Engineering, University of Vigo, Vigo \\ Campus of Lagoas Marcosende, 36310 Vigo, Spain, \\ phone: : (+34) 986812 685, e-mail: donsion@vigo.es
}

\section{Introduction}

This work deals with modeling and simulation of PV system which can be connected to the distribution power network. It means photovoltaic array. I try to draw up a specification of PV array problems because these sources have certain specific features, that are given by their characters. I give a attention to the characteristics of PV cells that influence the reliability and quality of the power supply. I also deal with these behaviour of PV array in the distribution grid, their possible influence on a voltage regulation, influence of their power variation on voltage waveform at the point of connection and also an examination of different variants of PV array connection.

\section{Key words:}

Microgrids, renewable energy, renewable power sources, optimalization, PV cell, mathematical model of PV cell, Swing

\section{Mathematical model of PV cell}

We can substitute PV cell by equivalent electric circuit where is included a power supply and a diode. The power supply produce the current $\mathrm{I}_{\mathrm{ph}}$ which depends on impinging radiation. Through diode flows the current $I_{D}$. The current I which flows to load is difference between $I_{p h}$ and $I_{D}$ and it is reduced by the resistance $R_{S}$ which represents resistance of cell and connection among cells.

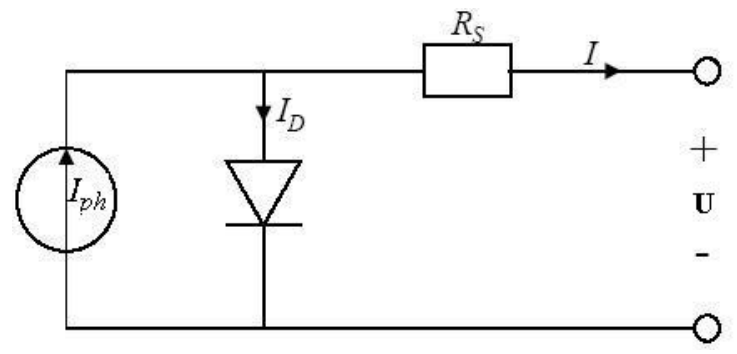

Fig 1: Equivalent electric circuit of PV cell

The cell has a constant current while the voltage go up until specific value and after that current go down steeply to zero - diode is opening, $\mathrm{I}_{\mathrm{D}}$ goes up. It is shown in

Fig 2.



Fig 2: Typical Voltampere characteristic of PV cell

If we connect a resistive load $\mathrm{R}$ to cell then working point of cell will be on crossing point voltampere characteristic of cell and load characteristic. Voltampere characteristic of load is a straight line with slope $1 / \mathrm{R}$. If value of $\mathrm{R}$ is too low, the working point is in area between $\mathrm{M}$ and $\mathrm{N}$ where cell behaves like constant current source. It is more or less short curcuit current. But if value of $\mathrm{R}$ is high, the working point is in area between $\mathrm{P}$ and $\mathrm{S}$ where cell behaves like constant voltage source. It means about a open circuit voltage.

Connection with optimal resistance $\mathrm{R}_{\mathrm{opt}}$ means that PV cell generates maximum output power which is given to product of voltage $U_{m}$ and current $I_{m}$. Working point where is the maximum of power and efficiency is in the flexion of voltampere characteristic.

In Fig 3, an voltampere charastecistic of a PV cell for only a certain ambient irradiation $\mathrm{G}_{\mathrm{a}}$ and only a certain cell temperature $T_{c}$ is illustrated. The influence of the ambient irradiation $G_{a}$ and the cell temperature $T_{c}$ on the cell characteristics in presented in Fig 4.

Fig 3 shows that the open circuit voltage increases logarithmically with the ambient irradiation while the short circuit current is a linear function of the ambient irradiation. The arrow shows in which sense the irradiation and the cell temperature, respectively, increase. The influence of the cell temperature on the voltampere charasteristics is illustrated in Fig 4. The dominant effect with increasing cell's temperature is the linear decrease of the open circuit voltage, the cell being thus less efficient. The short circuit current slightly increases with cell temperature. 


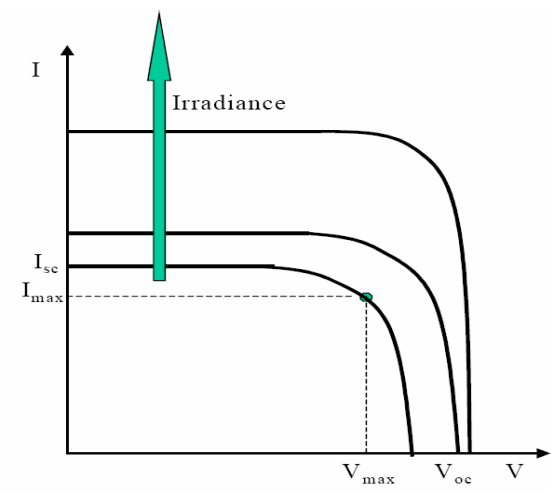

Fig 3: Influence of the ambient irradiation on the cell charasteristics

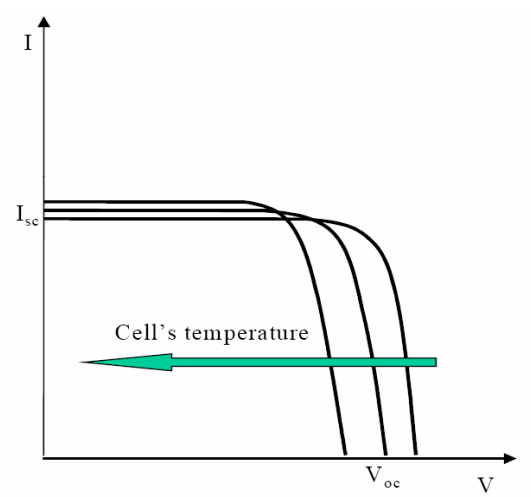

Fig 4: Influence of the cell temperature on the cell charasteristics

For practical use, PV cells can be electrical connected in different ways: series or parallel. Fig 5 and Fig 6 present how the voltampere curve is modified in the cases when two identical cells are connected in series and in parallel.

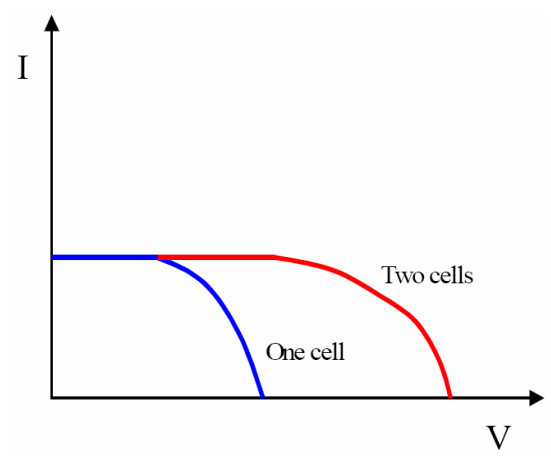

Fig 5. Series connection of identical cells

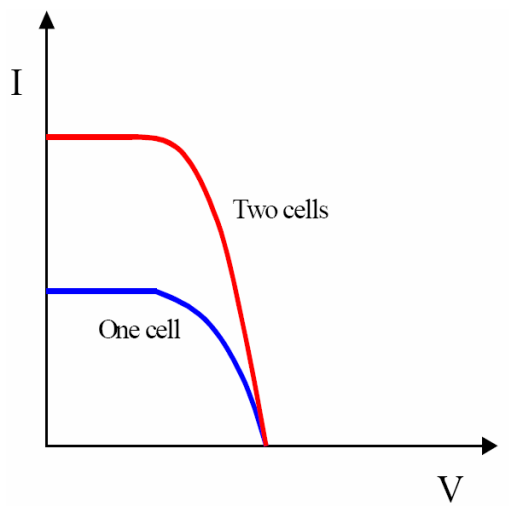

Fig 6. Parallel connection of identical cells
It is seen that voltampere characteristics of series interconnected cells can be found by adding, for each current, the different voltages of the individual cells. On the other hand, for parallel cells the currents of the individual cells must be added at each voltage in order to find the overall voltampere curve.

\section{Parametres of PV cell for normal specification}

standard conditions:

$$
\begin{aligned}
& \text { Impinging radiation } \mathrm{G}_{\mathrm{a}, 0}=1000 \mathrm{~W} / \mathrm{m}^{2} \\
& \text { Temperature of cell } \mathrm{t}^{\mathrm{C}}{ }_{0}=22{ }^{\circ} \mathrm{C} \text {. }
\end{aligned}
$$

a) short circuit current $\mathbf{I}_{\mathbf{S C}, \mathbf{0}}^{\mathbf{C}_{\mathbf{O}}}$ - the maximum current generated by cell with short-circuited output, $\left(\mathrm{U}^{\mathrm{C}}=0\right)$.

b) open circuit voltage $\mathbf{U}^{\mathrm{C}}{ }_{\mathbf{O C}, \boldsymbol{0}}$ - the maximum voltage of cell with disconnected output $\left(\mathrm{I}^{\mathrm{C}}=0\right)$.

c) maximum power $\mathbf{P}_{\mathbf{m}, \mathbf{0}}^{\mathbf{C}}-$ maximum power of cell, $\mathrm{P}_{\mathrm{m}, 0}^{\mathrm{C}}=\mathrm{U}_{\mathrm{m}}^{\mathrm{C}} * \mathrm{I}_{\mathrm{m}}^{\mathrm{C}}[\mathrm{W}]$

From these parametres we can assign so called the Fill Factor: $\mathrm{FF}=\mathrm{U}_{\mathrm{m}} * \mathrm{I}_{\mathrm{m}} / \mathrm{U}_{\mathrm{SC}} * \mathrm{I}_{\mathrm{SC}}[-]$

The Fill Factor for good cells would be higher than 0,7.

All parametres are valid only for standard condition. If impinging radiation $\mathrm{G}_{\mathrm{a}}$ or temperature of cell $\mathrm{t}^{\mathrm{c}}$ change, then open circuit voltage, short circuit current and flexion of voltampere characteristic change as well.

\section{Parameter change of $P V$ cell by influence of change $G$} and $\mathbf{t}^{\mathrm{c}}$

1) Influence of $G$

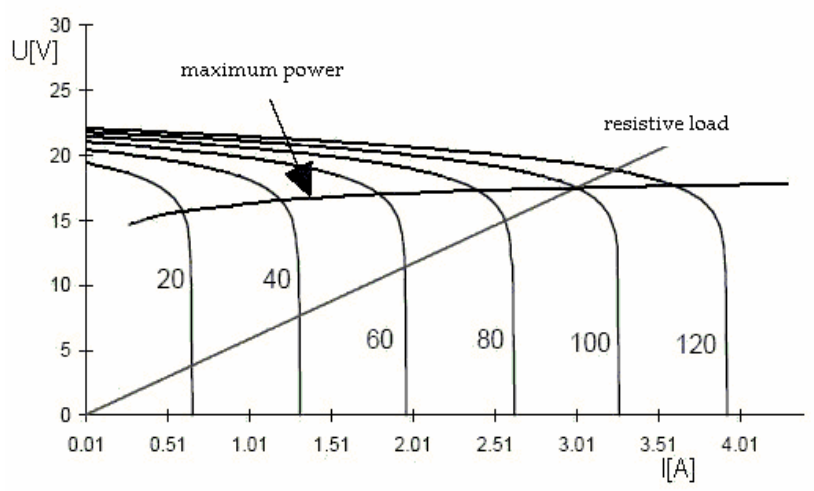

Fig 7. Influence of radiation change $\mathrm{G}\left[\left(\mathrm{W} / \mathrm{m}^{2}\right) * 0,1\right]$ on current and voltage of PV cell.

Open circuit voltage go up logarithmic when impinging radiation go up but short circuit current go up linearly. 
2) Influence of $t^{c}$

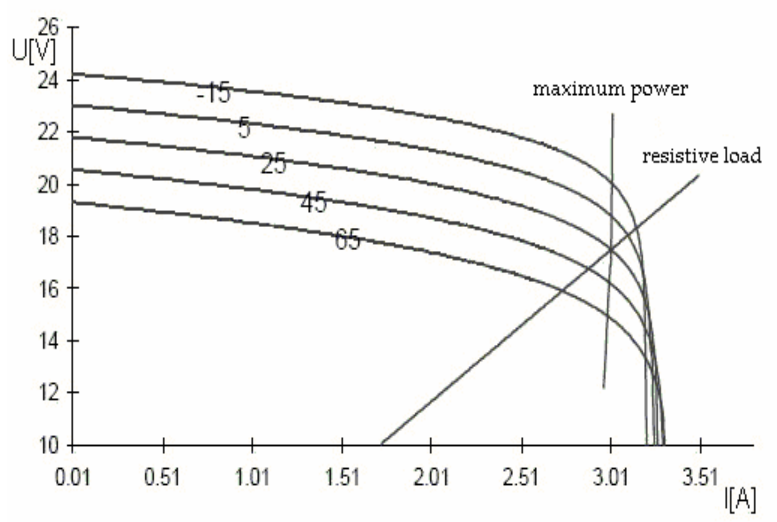

Fig 8. Influence of temperature change $\mathrm{t}_{\mathrm{c}}\left[{ }^{\circ} \mathrm{C}\right]$ on current and voltage of PV cell

When temperature of PV cell go up then open circuit voltage go down linearly and short circuit current go up.

\section{Equation describing a behavior of PV cell}

a) Equation for computation of $\mathrm{PV}$ cell current $\mathrm{I}^{\mathrm{C}}$ depending on impress voltage $\mathrm{U}^{\mathrm{C}}$.

(it describes waveform of voltampere characteristic):

$$
\left.I^{C}=I_{S C}^{C} \mid 1-\exp \left(U^{C}-U_{o c}^{C} / U_{t}^{C} * m\right)\right]
$$

b) Computation of short circuit current depending on impinging radiation $\mathrm{G}_{\mathrm{a}}$ and temperature of cell $\mathrm{T}^{\mathrm{C}}$ :

$$
\begin{gathered}
I_{S C}^{C}=C 1 * G a+k 1 *\left(T^{C}-T_{0}^{C}\right) \\
\mathrm{T}_{0}^{\mathrm{C}}=273,15+\mathrm{t}_{0}^{\mathrm{C}}=295,15[\mathrm{~K}]
\end{gathered}
$$

c) Computation of open circuit voltage depending on impinging radiation $\mathrm{G}_{\mathrm{a}}$ and temperature of cell $\mathrm{T}^{\mathrm{C}}$ :

$$
U_{o C}^{C}=U_{o C, 0}^{C}+C 3 *\left(T^{C}-T_{0}^{C}\right)-\exp \left(\frac{G a-G a 0}{K 3}\right) / K 4
$$

d) Computation of cell temperature depending on ambient temperature and impinging radiation $\mathrm{Ga}$ :

$$
T^{C}=t_{a}+273,15+C 2 * G a
$$

Impinging radiation Ga gives a rise to a heating effect of PV cell.

e) Computation of so called the thermal voltage depending on temperature of cell:

$$
U_{t}^{C}=k^{*} T^{C} / e \quad[\mathrm{~V}]
$$

Constant $\mathbf{k}=1,381 * 10^{-23}[\mathrm{~J} / \mathrm{K}]$ is Boltzmann's constant. Constant $\mathbf{e}=1,602 * 10^{-19}[\mathrm{C}]$ is elementary electric charge.

Constants $\mathrm{C}_{1}, \mathrm{C}_{2}, \mathrm{C}_{3}, \mathrm{~K}_{3}, \mathrm{~K}_{4}$ are different for different materials. It depends on cells.

\section{Real 20 kWp PV system}

On the roof of building of Faculty of Electroengineering in Pilsen is installed $20 \mathrm{kWp}$ PV system which is connected to public grid.

The PV system consist of 192 dark blue monocrystalline silicon solar cell modules which are produced by company Isofoton. The specific color of cells was choosen because of the best efficiency of these cells in the time when the system was installed. There are used 8 single-phase DC/AC converters of SunProfi SP 2500. Power consumption of the inverters is covered by solar system itself and the output is symmetrically phased to building's supply grid on $230 \mathrm{~V} / 400 \mathrm{~V}$. The connection to building grid is directly throught switchboard. Own block transformer is not used because of lowering purchase costs. The array is mounted on building roof, situated soutbound and inclined in $45^{\circ}$ angle. The fixed inclination is compromise for full year operation and low putchase costs.

Parametres of cell www.isofoton.com:

Measurement conditions:

- radiation: $1000 \mathrm{~W} / \mathrm{m}^{2}$

- temperature: $25^{\circ} \mathrm{C}$

Physical:

- Area of cell: 104,4 $\mathrm{cm}^{2}$ (cells 103)

- Large SolarModules I-110 (24V)

- dimension: 1310 x 654 x 39,5

- weight $(\mathrm{kg}): 11,5$

- Number of cells in serie: 72

- Number od cells in parallel: 1

- NOTC $\left({ }^{\circ} \mathrm{C}\right): 47$

- Type of cell: Monocrystalline Silicon 103 x 103

Electrical:

- Nominal voltage (V): 24

- Maximum power (Wp $\pm 10 \%): 110$

- Short circuit current (A): 3,38

- Open circuit voltage (V): 43,2

- Maximum power current (A): 3,16

- Maximum power voltage (V): 34,8

Whole PV system consists 8 the same parts with the same power output. Only one of them has components for measurement and monitoring. For good data evaluation of PV array outputs are measured some values like irradiation on horizontal plane, generator array plane irradiation, ambient temperature in the shade, reference sensor temperature, generator cell temperature, generator voltage, generator current, generator power and inverter AC power out. All these parametres are written down to computer file txt every 10 minutes. We can see in this file also maximum and minimum of all these values for 10 minute time period. Then we can analyse measured values and we can compare these parametres with math model of PV array.

These presented measurements were made while almost ideal operation conditionsfor photovoltaic system. That means constant and hight level of solar irradiance and good weather conditions. 


\section{Model of PV array}

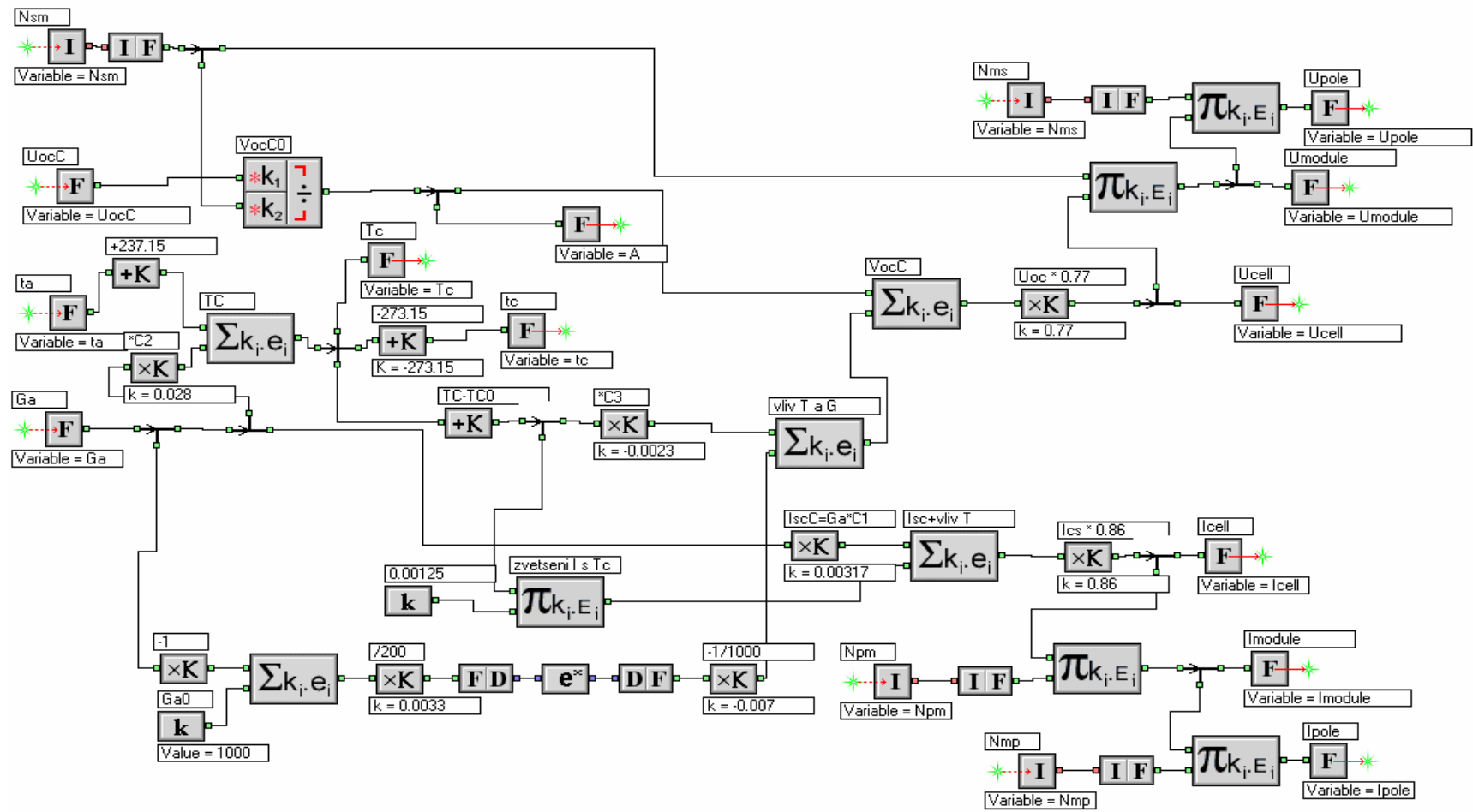

Fig. 9. Block math model of PV array in computer program Swing - Controlix

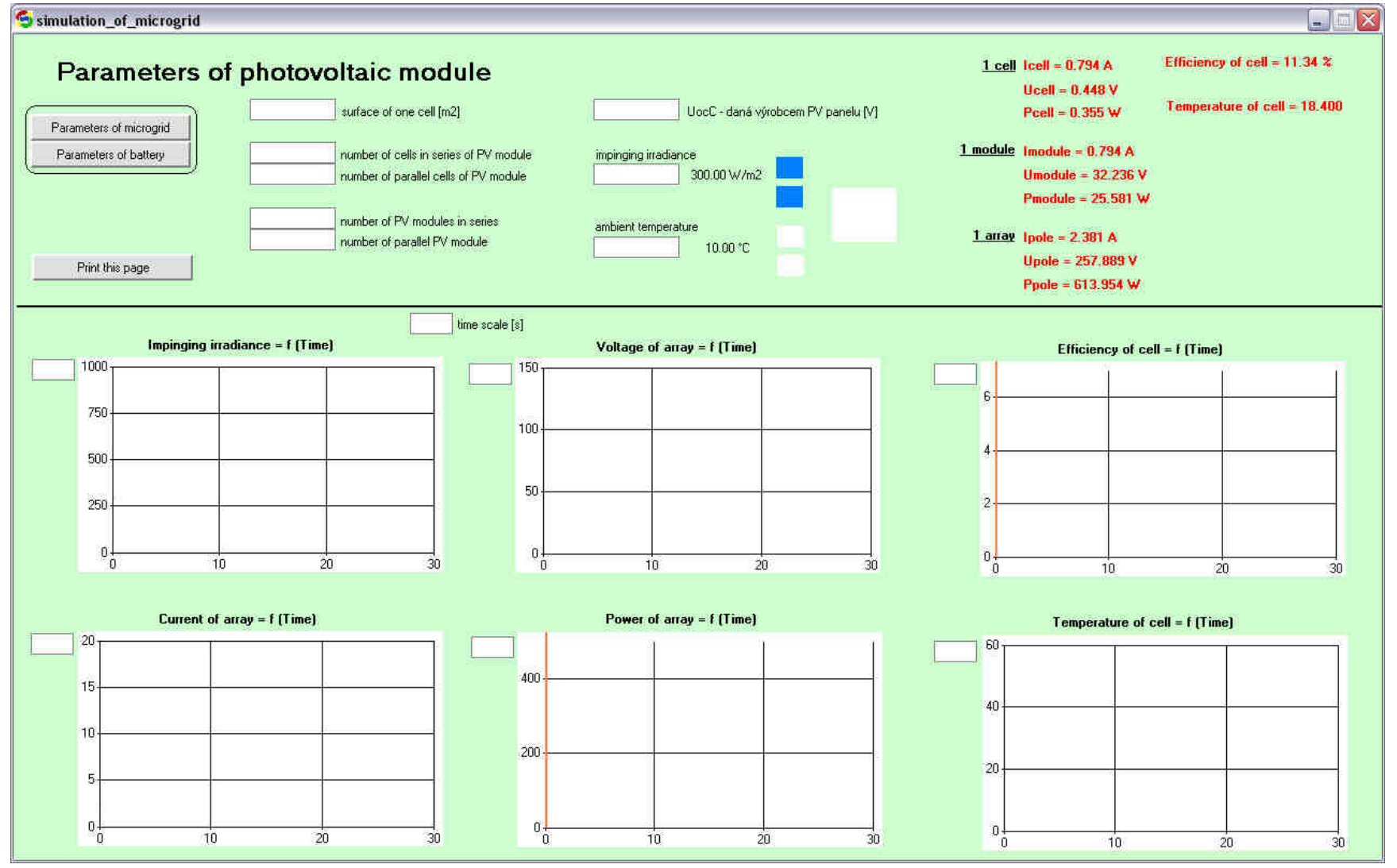

Fig. 10. Screen of running computer program Swing for PV array 


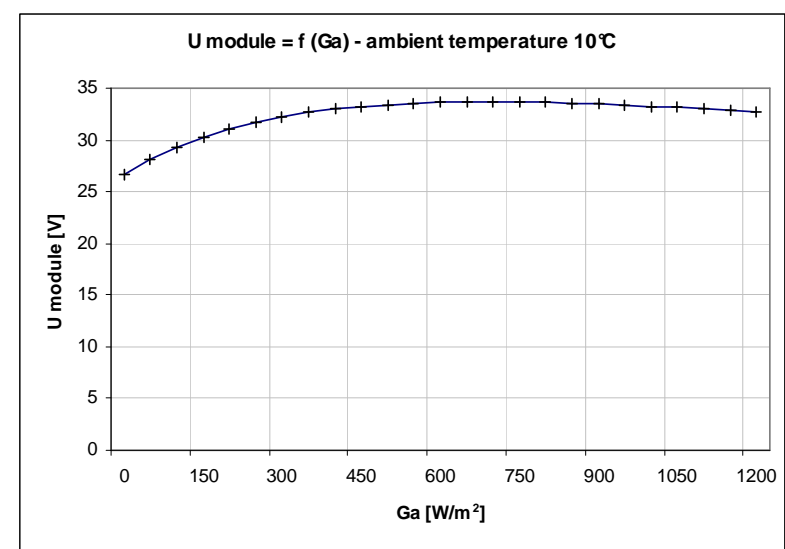

Fig 11. Umodule $=\mathrm{f}($ global irradiance $)$

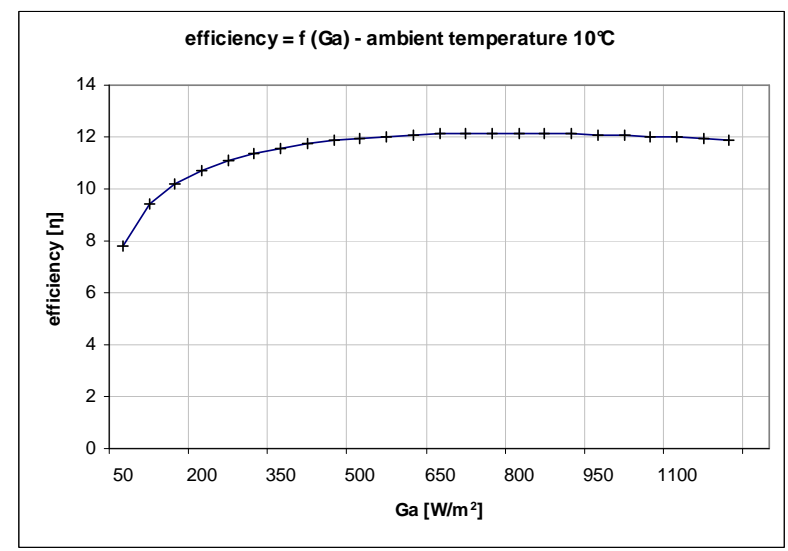

Fig 12. Efficiency $=\mathrm{f}($ global irradiance $)$

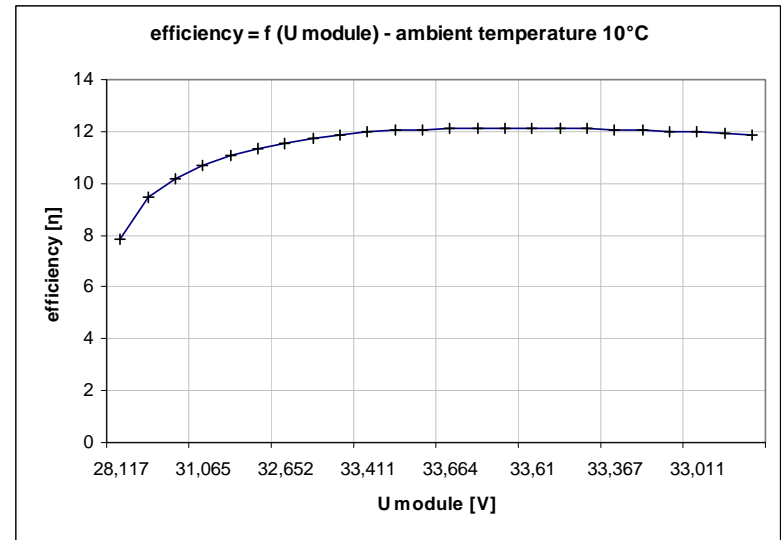

Fig 13. Efficiency $=\mathrm{f}(\mathrm{U}$ module $)$

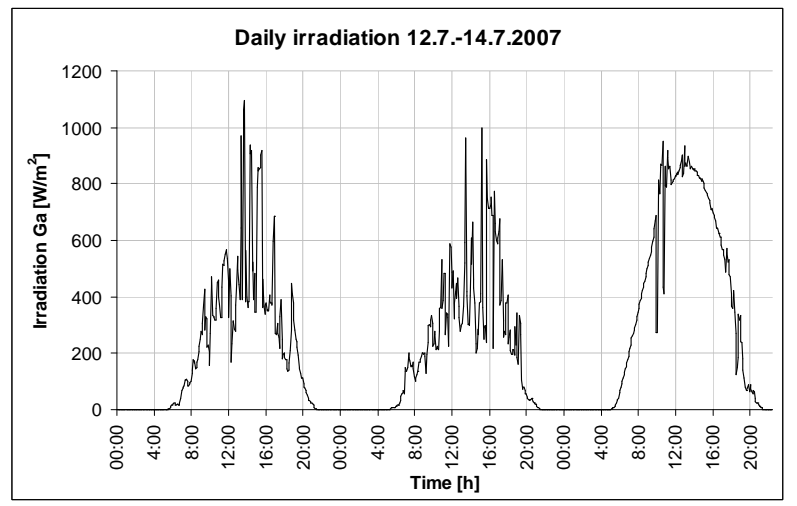

Fig 14. Daily irradiation $\mathrm{Ga}$ on the roof - measurement

\section{Conclusion}

Solar cells in PV array work only in part of voltampere characteristic near working point where is maximum voltage and maximum current. We assume that photovoltaic system works most of time with maximum efficiency. It means that for modeling of PV cell we should use constants for specific kind of cell near working point.

\section{References}

[1] Lorenzo, E.,: Electricidad solar - ingeniera de los sistemas fotovoltaicos, Universidad de Polítecnica de Madrid, PROGENSA, Spain, 1994

[2] Luque, A., Hegedus, S.,: Handbook of photovoltaic science and engineering, Universidad de Polítecnica de Madrid, University of Deleware, WILAY, Spain, USA, 2003

[3] Skočil, T.,: Interconnection Optimalization of Power Units with Renewable Power Sources (RES) to Distribution Network, University of West Bohemia, Plzeň, 2008

[4] http://www.solar2006.org/presentations/tech_sessions/ t61-99024.pdf

[5] http://ieeexplore.ieee.org/iel3/4263/12206/00564054.p df?arnumber $=564054$

[6] http://sel.me.wisc.edu/trnsys/downloads/trnsedapps/de mos/pvh-array.htm 